\title{
COVID-19 on Women Entrepreneurship Sustainability in Sarawak
}

\author{
Patricia Chua*1 $^{1}$ and Rashidah Kamarulzaman ${ }^{2}$ \\ ${ }^{1,2}$ Department of Marketing, School of Business and Management \\ University of Technology Sarawak, \\ No. 1, Jalan Universiti, 96000 Sibu, \\ Sarawak. Malaysia. \\ *Corresponding author: mbm20030001@ student.ucts.educ.my
}

\begin{abstract}
The COVID-19 pandemic has affected the businesses upside down, and the women entrepreneurs have to deal with the impacts that are affecting them during this pandemic and find ways to resolve the impacts to sustain their businesses. The purpose of this research is to look into the sufficiency of the support given in financial, government, education, and association bodies in sustaining the women entrepreneurs during COVID-19 with the effects of the COVID-19 on women's entrepreneurship in Sarawak. Through in-depth interviews with experts, the study employs a qualitative research approach. Women entrepreneurs and relevant bodies such as policymakers, Majlis Amanah Rakyat (MARA), National Association of Women Entrepreneurs of Malaysia (NAWEM), banks, and the State Financials Secretary were interviewed in order to analyse the implications. In order to acquire data and information for this study, 31 participants from women entrepreneurs and related organisations were interviewed. The findings show that women entrepreneurs in Sarawak are seeing a decrease in sales, a change in the nature of their business, supply chain disruption, and a change in their business model. This study will contribute to the provision of new data because there has been a shortage of research on women's entrepreneurial sustainability in Sarawak during COVID-19, resulting in fresh data that is primary data.
\end{abstract}

Keywords: Entrepreneurship, COVID-19, Pandemic, Sustainability

\section{Background of Study}

The COVID-19 pandemic, which is currently impacting many aspects of our lives, including the country's economy, is the world's most pressing question. According to Fairlie (2020), COVID-19 has had an impact on women entrepreneurs in the United States in terms of financial losses owing to social distance constraints, resulting in a 16 percent fall in the number of women entrepreneurs from 5.4 million to 4.5 million. According to the Department of Statistics Malaysia, the total number of entrepreneurs registered with the Companies Commission of Malaysia (SSM) in the newly-released Economic Census in 2016 is 907065 , which represents 98.5 percent of the total establishment of 920624 firms and 20.6 percent owned by women. There was an increase from the year of 2010 to 2016 of 46.7 percent. New Sarawak Tribune (2017) mentioned that there are 500,000 small and medium enterprises (SMEs) registered in Sarawak. Women entrepreneurs are diversifying their family's income by contributing significantly to socioeconomic development (Al-shami, Muhamad, \& Rasyid, 2019). This demonstrates the importance of empowering women entrepreneurs so that they may 

19 when the economy is deteriorating and harming them. The goal of this research is to examine and debate the effects of COVID-19 on the sustainability of women's entrepreneurship in Sarawak. It has been reported that Malaysia under the MCO which only allows essential services to run except for the private premises and all offices. This would be a hard time for the women entrepreneurs as they would have to make a wise decision on how to handle their business during the MCO when they have to pay for rental, salaries of the workers and other commitments. This is supported by Christy (2020) in the New Straits Times that Khoo, an entrepreneur, mentioned that the MCO prevented the business to generate income even though the overheads, rental and salaries or the worker still to be met.

\section{Problem Statement}

Women entrepreneurs require considerable government support in the form of financial assistance, legislation, and standards. According to Bernama (2020), a Kuching-based handicraft entrepreneur had to rely only on savings after losing revenue due to the Movement Control Order, which cost her almost RM30,000 and prevented her from working for a period of time. As a result, government assistance is needed to help women entrepreneurs recover from business losses during COVID-19, such as allowing them to operate their businesses with certain restrictions; otherwise, women entrepreneurs would be forced to bear the losses on their own, potentially leading to bankruptcy.

Churchill (2020) stated that Sarawak's financial situation is already depressing, and that COVID-19 will exacerbate the economic disaster. One of the consequences is that women entrepreneurs are left behind and unable to fulfil their objectives. Cash is a barrier for women in building their businesses because capital is vital in an entrepreneurial organisation and sustainability (Orser, Riding, \& Manley, 2006).

Sarawak's Chief Minister, Datuk Patinggi Abang Johari Tun Openg, announced that the government has allocated RM1.1 billion as a second Bantuan Khas Sarawakku Sayang aid package for SMEs, micro enterprises, hawkers, and petty traders to assist them and lessen their burden during this difficult period. They will be given a RM1,500 special grant, which will be granted to those who have registered with the state local authorities.

The study's curriculum focused primarily on the COVID-19 and the firms touched by women entrepreneurs. According to Razak (2020), the Malaysian Trades Union Congress (MTUC) has warned that it will be difficult for all firms to recover since most likely, companies will be closed down to decrease operating costs. Women entrepreneurs should educate themselves by attending seminars or discussions on how to keep their businesses from closing down during the pandemic, and they can boost their productivity in their firms by coming up with new ideas and strategies to create sales during COVID-19.

Association bodies play a vital role in creating solutions to help entrepreneurs save their enterprises in a number of ways during the COVID-19 pandemic. Before the COVID-19 pandemic, Dato Sri Fatimah Abdullah, the Minister of Welfare, Community Wellbeing, Women, Family and Childhood Growth, declared that she encouraged women entrepreneurs to join association bodies to learn more about not only business but also other parts of life (New Sarawak Tribune, 2018). This is an eye opener for women entrepreneurs to join any association, whether it is a non-government 

organisation (NGO) to obtain information and expertise that would be helpful, and to gain assistance from the association, especially during this pandemic.

\section{Research Objectives}

i. To explore the sufficiency of government support towards women entrepreneur sustainability during COVID-19.

ii. To explore the sufficiency of financial support by government agencies towards women entrepreneur sustainability during COVID-19 in Sarawak.

iii. To explore the benefit of education towards women entrepreneur sustainability during COVID-19 in Sarawak.

iv. To explore the support given by association bodies of sustainability during COVID-19.

\section{Literature Review}

\section{Past Study on Women Sustainability}

In recent years, the number of women entrepreneurs have been breaking out in the entrepreneurial life and embracing the career as an alternative to higher economic growth. Evidently, the total number of small and medium-sized enterprises (SMEs) in Malaysia is 907,065 and the women entrepreneurs constitute 20.6 percent from the total (SMECORP, 2019). This is proven as in the informal economies, the women entrepreneurs continue to work despite of this pandemic and concern about their health (International Labour Organization (2020).

\section{Success of Women Entrepreneur in Sarawak}

In order for women entrepreneurs to operate and run small businesses that they own, they must manage according to their priorities and objectives (Mohamad and Bakar, 2017). Women must decide what they want to accomplish and be determined to work hard to achieve their goals and objectives. Based on the above, Sarawak has a small number of successful women entrepreneurs. According to the above, there are a few successful female entrepreneurs in Sarawak, such as Sereni Linggi and Shentel Lee, the founders of Sereni and Shentel Borneo headband. Sereni and Shentel are from Kuching, and their company has been in the market in about ten years. Their proudest accomplishment was when the brand was featured on a television show in the United States, where they said that the secret to their success was by collaborations (Yasmin, 2019). 


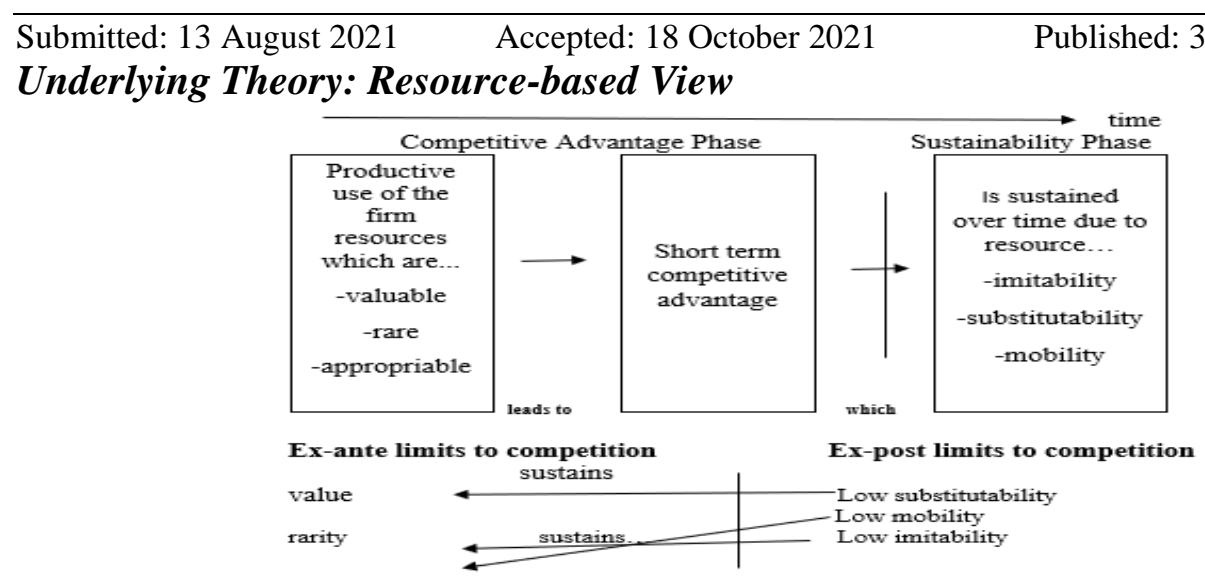

Figure 1: Resource-based View over Time Theory

Mweru and Maina (2015) mentioned that the Resource-based View (RBV) theory is based on the ability to contribute internal capability so as to create the sustainability of competitive advantage. In accordance to it, this theory can relate to this study by looking at all the available supports from government, financial, education, and association bodies to help the women entrepreneurs to sustain their business post COVID-19 in Sarawak but there is no guarantee that the support will be given in a long-time. This has been proven by Darcy, McCabe, and McGorven (2014) that in businesses, the obvious competitive resources are physical resources, financial resources, and organisational aspects and the key point towards sustainability is the endowment of resources that makes a difference from its competition and from there, the women entrepreneurs need to consider upon the competitive resources that which might be in the resource-based view. From the figure, it proves that the women entrepreneurs can benefit from the supports given to enhance and outgrow businesses as the resources are given so the women entrepreneurs need to make improvement and make their product valuable to sustain their business and also satisfy the customers' demand so both parties will have win-win situation. In conclusion, the Resource-based View theory is applied to this study whereby the Women Entrepreneurship optimising or utilising their resources in order for them to sustain their business.

\section{Independent Variable}

The independent variables in this study are government support, financial support, education, and association bodies. Investigation of existing literature reveals a significant gap of research related to the detailed performance and activities in entrepreneurship world.

\section{Government Support}

There is a growing concern for the development of women entrepreneurship globally in running and promoting their business due to this hard time. According to Bernama (2020), Sandra, an entrepreneur from Kuching, said that her rattan company was seriously impacted during the Movement Control Order because there were no orders and the previous order could not be issued, causing payment to become stuck and no sales, despite the fact that she still had to pay the salaries of about 30 employees. Women's abilities and capabilities should not be neglected, and we should encourage 
women to run their businesses because their success would lead to economic development.

\section{Financial Support}

There's a strong possibility that women entrepreneurs will face financial difficulties during COVID-19, and it is not easy for them to get financial assistance in Malaysia because of the terms and conditions. According to Idris and Tan (2017), there is no institutions willing to fund in women's businesses over the long term. The reason is because of the outbreak caused the economy to collapse, and the economy would take some time to recover from this COVID-19. This is in accordance with Churchill's (2020) mentioned that Sarawak's financial situation is already alarming, and that COVID-19 would worsen the economic crisis. This barrier has been identified as they will be able to refer to their relatives and spouses for getting alternative financial support for the women entrepreneur who experiences limited access to the capital. Consequently, this action leads to stereotyping women entrepreneurs as not money savvy.

\section{Education}

Women entrepreneurs should think before making decisions about their businesses, particularly during this challenging time, and seek advice and guidance from experienced individuals on ways to save their businesses. According to The Star (2020), technology adoption can be initiated especially for small and medium-sized enterprises (SMEs) as their organization to be more resistance. During the COVID-19 pandemic, now would be a great time to teach women entrepreneurs how to use technology to market their goods and services, since less customers will be going to the store or office to purchase or get services to avoid the growing number of COVID-19 despite the government's announcement that companies will operate as normal by following SOP.

\section{Association Bodies}

According to Brittany (2020) of Forbes Women, business entrepreneurs are affected economically by the COVID-19, and women entrepreneurs have a constantly changing tide. So, this is a worrying issue for women entrepreneurs who are trying to find out how to save their businesses, and now is the perfect time for association bodies to step in and help the entrepreneurs. There are few associations in Malaysia that provide assistance to small and medium-sized businesses (SMEs) and micro-entrepreneurs. The digitalisation of business operations through online discussion dated 17 April, in which the women's association is hosting a webinar to assist women entrepreneurs in their businesses during COVID-19 by providing information and advice from MDEC, industry experts, and business chambers.

\section{Dependent Variable: Sustainability of women entrepreneur in Sarawak}

Kong (2020) stated that sustainability in Sarawak can be achieved based on two principles which are the digital economy and environmental sustainability by developing economics, social, and governance sectors post COVID-19. This is proven business affect the economy of Sarawak so in order to sustain the economy, the entrepreneurs need to sustain their business especially during this pandemic. This pandemic not only affecting the business but also the tourism. In accordance to this, Kong (2020) mentioned that the state is putting effort to help the tourism industry through products developments and key initiatives to help the tourism industry as it takes time to recover. The 
government is approaching the problem faced by the businesses to achieve sustainability COVID-19.

\section{Methodology}

\section{Research Approach}

According to Thomas (2003), several authors characterize the general inductive method as a technique in qualitative data in journals. Instead of collecting data to assess preconceived models, hypothesis, and theories, qualitative researchers would rather develop ideas, observations, and understand the pattern in the data. The research design of this study is qualitative methods in order to address the research questions. The research approach influences design and provides an opportunity to consider benefits and limitations of various approaches available to the researcher.

\section{Qualitative Research}

In this research, qualitative method is used as it has been confirmed by Jackson, Drummond, and Camara (2007) that qualitative research is an approach to explore and understand the meaning of individual and groups ascribe to human or social problems. The process of research involves collecting emerging questions and procedures from women entrepreneur. In order of choosing qualitative method, information about the impacts of women entrepreneurs, needs, desires, use cases, and a variety of other information that are important in conducting this research.

The approach is to examine the effect of post-COVID-19 on the sustainability of women's entrepreneurship in Sarawak. For this study, qualitative research is appropriate. Crescentini and Mainardi (2009) states that qualitative research is not a simple task since it requires a variety of skills such as listening attentively, taking notes, and planning and preparing adequately so that we can gain a deeper understanding knowledge with the multiple perspective that we get during the interview. In qualitative research, research questions are provided to focus on the perspectives and definitions of the impacts of women entrepreneurship.

\section{Purposive Sampling Method}

Etikan, Musa, and Alkassim (2016) mentioned that a purposive sampling method, also known as judgement sampling, is a non-profitability sample that selects participants based on the quality process and specific objective. For this study, the main respondents are mostly from the women entrepreneurs in the small and medium-sized enterprises in Sarawak and from the policy maker, Majlis Amanah Rakyat (MARA), National Association of Women Entrepreneurs of Malaysia (NAWEM), bank and State Financials' Secretary. Tongco (2007) mentioned that in the purposive sampling method, the researcher had to determine what information is needed for the study and find individuals that are willing to contribute information based on their experiences or knowledge. As for this study, the respondents have been selected which is the women entrepreneurs, policymaker, association bodies, and State Financials' Secretary as to obtain data and information.

\section{Data Collection}

This study used interviews to obtain the feedback for the research questions. It is because the study is based on qualitative analysis. As a result, the best way to approach a subject 

Neale (2006), an interview is a qualitative research technique that involves conducting individuals' interviews with a small number of respondents to examine their perspectives on a subject, idea, or situation. To gather data for this study, women entrepreneurs and other organisations were interviewed.

This study used focus group method in order to get information and opinion from different individuals. Karen, Effat, and James (2014) mentioned that a focus group is used for qualitative research which involves blending techniques to obtain data. In order to get information about the impact of COVID-19 on women entrepreneurs' sustainability in Sarawak, a focus group research method was done to get more punctual respond by discussing among the selected individual during the discussion. The purpose of doing focus group was to develop interview questions.

In order to perform this study, there were up to 31 respondents who were required to provide information and data. Women entrepreneurs between the ages of 25 and 55 who operate/own small and medium-sized businesses was the respondent's characteristic develop interview questions. The main objectives for interviewing the women entrepreneurs are to get the information regarding the impacts of COVID-19 on women sustainability in Sarawak. Apart from women entrepreneur, a total of 5 respondents is representatives from the policy maker, State Financials' Secretary and association bodies were interviewed for this study. The purpose of interviewing the respondent is to have a comprehensive thorough investigation by looking at two perspectives.

The data collection activities have been commenced since February 2021. However, due to the surge of COVID-19 in Sibu, the government has imposed the Control Movement Control Order (CMCO). Henceforth, the data collection activities have slowed down. Currently, the study managed to collect a total of 20 responses from the women entrepreneurs. Once the process of data collection completed, then this study will begin to analyse the data by using the ATLAS.ti.

\section{Data Analysis}

This study will be using ATLAS.ti software as a vital tool for in the process of data analysis for better understanding. ATLAS.ti helps the researcher by systematically analyse complex phenomena hidden in the unstructured data such as text multimedia and geospatial (Friese, 2014). Romero (2016) stated that the function of ATLAS.ti software is to extend the mental capacity, support data analysis, remembering, and being systematic. Friese (2014) mentioned that ATLAS.ti is a data management tool for the researcher where the software able to manage, organize and sort through the data corpus. This software will useful for the researcher to conduct their study as this software is systematic in managing the data. Verma (2016) stated that there is multitude feature in the ATLAS.ti software but the main features are the Hermeneutic Unit (HU) and from this, the two key tools can be used in order to explore qualitative data. This study will be using ATLAS.ti as this software keeps track of the important data such as notes, and primary material such as text, audio, and image which is required in this study during the interview session. 


\section{Discussion and Results Analysis}

According to an interview with Sarawakian women entrepreneurs, they are seeing effects such as decreased sales, a shift in the nature of their business, supply chain disruption, and a shift in their business model. According to the impacted women businesses, sales have plummeted by more than 50 percent as a result of the COVID-19 outbreak, and one of the respondents has had to change the type of her firm to absorb the complete losses. Aside from that, there is a disruption in the supply chain, which causes delivery and production costs to rise, forcing women entrepreneurs to pay more at a time when they are already struggling.

Due to the government's restrictions on operating time and rules that must be obeyed, the shifting modus operandi has an impact on company. Approximately $70 \%$ of the women entrepreneurs polled claimed COVID-19 had a significant impact on their business. According to Hamdan, Kassim, and Lai (2021), the MCO has triggered operational disruptions in microenterprises, causing them to confront financial difficulties as a result of increased transport and manufacturing costs.

The findings on government support revealed that women entrepreneurs lack BKSS information, face application failure, receive adequate and beneficial support, and some claim to receive insufficient support. A total of $30 \%$ of the people polled said that the application process has a lot of criteria. However, half of those polled believe that the government's assistance will help them cope with the pandemic. Nilawati from ND Beauty, one of the responses, stated that the RM3k in support from GKP has helped her a lot in terms of making her own product and she is able to keep rolling the money, which she believes is sufficient and advantageous to her business. During this pandemic, government assistance to entrepreneurs is critical in order for them to build their businesses. Failure to apply for benefits such as BKSS and PRIHATIN is also a problem. This is due to errors made when filling out the paperwork, such as putting partnership instead of SDN BHD on the form.

In addition, the interview resulted in insufficient support. According to the survey, almost half of the respondents felt that the assistance provided was insufficient. Sam (2021) noted that there were obstacles such as insufficient cash flow, business losses, and high costs, and he hoped that the government would provide incentives such as rental discounts, interest-free loans, and salary subsidies in the next assistance package.

The interviews revealed that, in addition to government assistance, women entrepreneurs are receiving financial assistance from various institutions, and that most enterprises are experiencing cash flow issues as a result of the COVID-19 outbreak. The respondents demonstrated that some of them need to spend their personal funds since they have no one else to turn to and are frightened to take out loans to relieve their financial load. There is also evidence that no financial assistance is required because women businesses are still able to survive. Due to the crisis, MARA and TEKUN have created a scheme specifically for COVID-19, where women entrepreneurs can apply by meeting the requirements. Furthermore, the findings suggest that $20 \%$ of respondents agreed that that there is no financial support needed as they are still able to survive on their own.

During COVID-19, it was discovered that 80 percent of respondents felt that education plays a vital role in education, and that seminars are held to improve skills and provide advice and inspiration by government and non-government entities to educate 

entrepreneurship success. Skills development, according to the International Labour Organization (2020), increases people's abilities to work as well as their possibilities at work, resulting in greater innovation and better performers. Women entrepreneurs can improve their talents in order to empower women's development and productivity in the workplace.

In terms of association bodies, it was discovered that there was no participation and that some people were ignorant of any association bodies, while others stated that they had received assistance and support from them. They are virtual services provided by association bodies during COVID-19, such as training, seminars, and entrepreneurial activities. Also, if the pandemic continues, it will be necessary to focus on marketing and promotion, save money, and collaborate. These are all of the steps that entrepreneurs will take to keep their business from shutting down.

Finally, based on the study from the second perspective, it appears that the government provides assistance, but that some recipients do not receive it due to the specified requirements. Apart from the government, MARA and TEKUN, according to an interview, provide schemes to assist affected entrepreneurs. NAWEM and WEPS, for example, offer seminars, training, and a mentor mentee programme to teach and refine entrepreneurs' abilities while also providing information. NAWEM and WEPS investigate the support provided by the government or non-government organisations to women entrepreneurs by informing them of the details and resources available. All of the finding above needs to be solved in order to help the women entrepreneurs in sustaining their business and operating their business smoothly.

\section{Table 1: Summary of How Covid-19 has impacted women entrepreneurship in Sarawak}

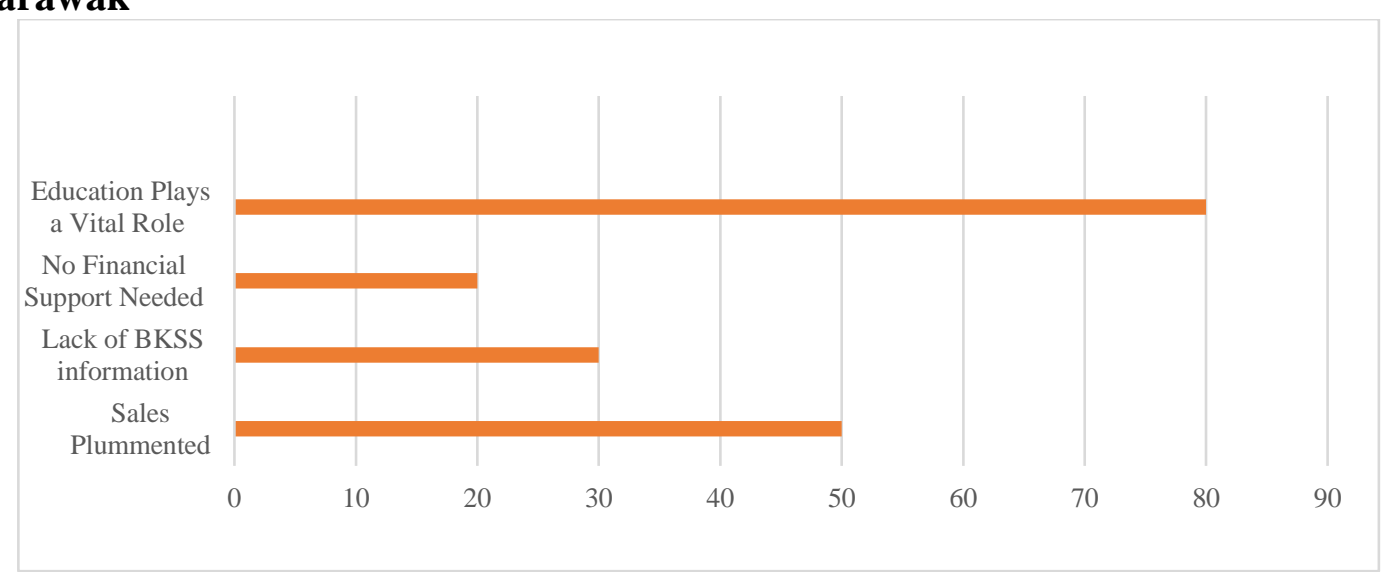

Source: Author

\section{Contribution}

This study aided women entrepreneurs in Sarawak in understanding the effects of COVID-19 on women's enterprise sustainability. Women entrepreneurs must place a high priority on education, since having a broad and comprehensive knowledge base would enable them to address all issues and sustain their enterprises. According to Stam and Garnsey (2008), policymakers all over the world are relying on entrepreneurship to drive economic growth, which has led to a greater understanding of the importance of business in the knowledge economy. As a result, women entrepreneurs must be 

mentor mentee programmes, seminars, and webinars are offered to educate entrepreneurs, from which they should benefit in order to sustain their businesses. Education is critical because knowledge can improve a company's or organization's efficiency and productivity. Aside from that, policymakers play a crucial role in assisting women entrepreneurs in their pursuit of economic growth and empowerment. According to the OECD (2004), policymakers should pay attention to the voices of women entrepreneurs and create government offices dedicated to women's business ownership, which can be used for programmes such as organising information seminars and meetings or providing web-based information to women who are currently business owners and have valuable insights into the industry. The information of this study can be used by the policy maker to study the difficulties that the women entrepreneurs are facing, which will enable the policy maker to take action to help the women entrepreneurs during this pandemic of Covid-19.

\section{Conclusion}

In conclusion, this qualitative study is to explore the impacts of Covid-19 on women entrepreneurship on their businesses and relates it with the resource-based view by understanding the short-term survival strategies. This study has shown that the women entrepreneurs are facing financial problem due to losing income, disruption in supply change, changing business nature and operational problem on their businesses. There are supports given for them to utilize to sustain their business as from the government, financial, education and association bodies. Therefore, it is crucial for the women entrepreneurs to prepare savings mainly for their business so they can rely on the savings during unforeseen emergency to cover up the cost of operation. The women entrepreneurs also should prepare a creative and strategic business plan in case the pandemic of Covid-19 prolong. It was agreed by the association bodies and the government that digitalization is important to do promotions and marketing which the women entrepreneurs can educate themselves on the effectiveness and invest in the technology. The last measure is women entrepreneurs need to be aware and educate themselves on the knowledge, current issues, build connections by joining association bodies so they can expand their connectivity, share knowledge and learn from the programs organized so they are able to tackle problems and be motivated during Covid19.

\section{References}

Al-shami, S.S.A., Muhamad, M.R., Majid, I., \& Rashid, N. (2019). Women's entrepreneurs' micro and small business performance: insights from Malaysian microcredit. International Journal of Entrepreneurship and Small Business, 38(3), 312-338.

Bernama. (2020). More help needed to sustain SME businesses and people's livelihood associations. Astro Awani. Retrieved on 15 July 2021. Retrieved from https://www.astroawani.com.

Boyce, C. \& Neale, P. (2006). Conducting in-depth interviews: A guide for designing and conducting in-depth interviews for evaluation input, 1-12. 
Submitted: 13 August 2021 Accepted: 18 October 2021 Published: 31 December 2021

Brittany. (2020). How women entrepreneurs are navigating the effects of Covid-19. Retrieved on 13 July 2021. Retrieved from https://www.forbes.com.

Christy, D. (2020). Covid-19: How many small Malaysian businesses, jobs will we lost? The New Straits Times. Retrieved on 14 July 2021 Retrieved on 13 July 2021 Retrieved from https://www.nst.com.

Crescentini, A. \& Mainardi, G. (2009). Qualitative research articles: guidelines, suggestions and needs. Journal of Workplace Learning.

Churchill. (2020). PM gives Sarawak approval to upgrade Covid-19 screening facilities. The Borneo Post. Retrieved on 16 July 2021. Retrieved from https://www.theborneopost.com.

Darcy, C., Hill, J., McCabe, T.J., \& McGovern, P. (2014). A consideration of organisational sustainability in the SME context: A resource-based view and composite model. European Journal of Training and Development, 38(5), 398414.

Etikan, I., Musa, S.A., \& Alkassim, R.S. (2016). Comparison of convenience sampling and purposive sampling. American Journal of Theoretical and Applied Statistics, $5(1), 1-4$.

Friese, S. (2014). Implementing different analysis approaches with ATLAS.ti.

Fairlie, R.W. (2020). The impact of covid-19 on small business owners: The first three months after social-distancing restrictions (No. w27462). National Bureau of Economic Research.

Hamdan, N.H.B., Kassim, S.B.H., \& Lai, P.C. (2021). The Covid-19 Pandemic Crisis on Micro-entrepreneurs in Malaysia: Impact and Mitigation Approaches. Journal of Global Business and Social Entrepreneurship (GBSE), 7(20), 52-64.

Idris, N. \& Tan, J. (2017). Review of literature on women entrepreneurs. Journal of Global Business and Social Entrepreneurship (GBSE), 1(3), 1-11.

International Labour Organization. (2020). The impact of the COVID-19 pandemic on jobs and incomes in G20 economies. Retrieved on 17 July 2021. Retrieved from https://www.ilo.org/.

Jackson, R.L., Drummond, D.K., \& Camara, S. (2007). What is qualitative research?. Qualitative Research Reports in Communication, 8(1), 21-28.

Kong, S. (July 19. 2020). Sarawak steps up with SEAC. Borneo Post Online. Retrieved from https://www.theborneopost.com/2020/07/19/sarawak-steps-up-with-seac/.

Karen, T.L., Rankin, J.A., \& Ali, E. (2014). Focus group research: What is it and how can it be used? Canadian Journal of Cardiovascular Nursing, 24(1), 16-22.

Mohamad, M. \& Bakar, M.S. (2017). Malay women entrepreneurial success: Challenges and barriers. International Journal of Accounting, 2(5), 76-84.

Mweru, M.C. \& Maina, T.M. (2016). Features of resource-based view theory: An effective strategy in outsourcing. International Journal of Management and Commerce Innovations, 214-218.

New Sarawak Tribune. (2018). Women entrepreneurship body gives lots of benefits. New Sarawak Tribune. Retrieved on 17 July 2021. Retrieved from https://www.newsarawaktribune.com.

Orser, B.J., Riding, A.L., \& Manley, K. (2006). Women entrepreneurs and financial capital. Entrepreneurship Theory and Practice, 30(5), 643-665.

OECD. (2004). Women's Entrepreneurship: Issues and Policies. Retrieved on 19 July 2021. Retrieved from https://www.oecd.org/cfe/smes/. 
Submitted: 13 August $2021 \quad$ Accepted: 18 October $2021 \quad$ Published: 31 December 2021

Razak, A. (2020). Survey shows almost 97 percent of Malaysians benefitted from prihatin. The New Straits Times. Retrieved on 16 July 2021. Retrieved from https://www.nst.com.my

Romero, R.A.M. (2016). Qualitative Data Analysis with ATLAS.ti, por Susanne Friese. Qualitative Research in Education, 5(2), 226-228.

Sam, C. (2021). Prioritise Aid to Business Community, Put Major Projects on Back Burner, State Govt Urged. The Borneo Post. Retrieved from https://www.theborneopost.com.

Stam, E. \& Garnsey, E. (2008). Entrepreneurship in the knowledge economy. In Creating wealth from knowledge. Meeting the innovation challenge. pp. 14573.

SME Corp Malaysia. (2019). Government spent RM2.3 billion on women entrepreneurs in 2018. Retrieved on 17 July 2021. Retrieved from https://www.smecorp.gov.my.

Tongco, M.D.C. (2007). Purposive Sampling as a tool for informant selection. Ethnobotany Research and Applications, 5, 147-158.

Thomas, D.R. (2003). A general inductive approach for qualitative data analysis, 1-11. Retrieved from https://doi=10.1.1.462.5445\&rep=rep1\&type=pdf.

The Star. (2020). Covid-19 prompting major focus on online presence. The Star. Retrieved on 18 July 2021. Retrieved from https://www.thestar.com.my.

Verma, A. (2016). The ATLAS.Ti Qualitative Revolution. 56-58.

Yasmin, S. (2019). Sereni \& Shentel: A borneo headband brand lady gaga had a hand. Retrieved on 20 July 2021. Retrieved from https://www.astroawani.com. 